\title{
Cooling and concentration of nutrient solution in hydroponic lettuce crop
}

\author{
Nilton N Cometti'; Diene M Bremenkamp²; Karla Galon²; Leonardo R Hell ${ }^{3}$; Marinaldo F Zanotelli ${ }^{3}$ \\ ${ }^{1}$ Instituto Federal de Educação, Ciência e Tecnologia de Brasília (IFB), SGAN 610, Módulos D, E, F e G, $70860-100$ Brasília-DF; www. \\ niltoncometti.com.br; nilton.cometti@gmail.com; ${ }^{2}$ Universidade Federal do Espírito Santo (UFES-CCA), Alto Universitário s/n, 29500- \\ 000 Alegre-ES; dienemkamp@yahoo.com.br; karla_galon@hotmail.com; ${ }^{3}$ Instituto Federal do Espírito Santo (IFES), Campus Itapina, \\ BR 259 km 70,29709-910 Colatina-ES; leonardoraashhell@hotmail.com; mazanotelli@bol.com.br
}

\begin{abstract}
The study was conducted in greenhouse at horticulture department of the Instituto Federal do Espírito Santo, Campus Itapina, Colatina, northwestern Espírito Santo state, Brazil, with the objective of evaluating the effect of cooling and electrical conductivity of nutrient solution on growth and development of lettuce cv. Vitória de Santo Antão in hydroponics. The study was conducted in a completely randomized design with two factors (control of the maximum temperature of the nutrient solution: $26^{\circ} \mathrm{C}$ and without control; and electrical conductivity, EC, of the solution: 1,2 and $3 \mathrm{dS} \mathrm{m}^{-1}$ ) with three repetitions. The plants were harvested fifty-two days after sowing (DAS). We evaluated the dry and fresh mass of leaves, stems and roots, stem and root length, root volume and plant water content (\%). The temperature of the nutrient solution influenced the behavior of lettuce influenced by the electrical conductivity, showing that the increase of the EC did not reduce the lettuce productivity when the maximum temperature of the nutrient solution is limited, which in this experiment was tested at $26^{\circ} \mathrm{C}$. The cooling of the nutrient solution provided greater accumulation of mass and a higher water percentage in plants, increasing the productivity of hydroponic lettuce in tropical climate.
\end{abstract}

Keywords: Lactuca sativa, greenhouse, temperature.

\section{RESUMO}

Resfriamento e concentração da solução nutritiva em cultivo hidropônico da alface

O trabalho foi realizado em ambiente protegido, no setor de Horticultura do Instituto Federal do Espírito Santo, Campus Itapina, Colatina, região Noroeste do Espírito Santo, com o objetivo de estudar e avaliar o efeito do resfriamento e da condutividade elétrica da solução nutritiva no crescimento da alface cv. Vitória de Santo Antão em cultivo hidropônico. O trabalho foi realizado em delineamento experimental inteiramente casualizado com dois fatores (controle de temperatura máxima da solução nutritiva: $26^{\circ} \mathrm{C}$ e sem controle; e condutividade elétrica (EC) da solução: 1,2 e 3 dS $\mathrm{m}^{-1}$ e quatro repetições. Cinquenta e dois dias após a semeadura foi realizada a colheita das plantas e avaliados a massas frescas e secas de folha, caule e raiz, volume de raízes, comprimento do caule e das raízes e porcentagem de água nas plantas. A temperatura da solução nutritiva influenciou o desempenho da alface em função do aumento da condutividade elétrica, demonstrando que o aumento da EC não compromete a produtividade quando há limitação na temperatura máxima da solução nutritiva, que nesse experimento foi de $26^{\circ} \mathrm{C}$. O resfriamento da solução proporcionou maior acúmulo de massa e porcentagem superior de água presente nas plantas, aumentando a produtividade da alface hidropônica em condições de clima tropical.

Palavras-chave: Lactuca sativa, ambiente protegido, temperatura.

(Recebido para publicação em 2 de fevereiro de 2012; aceito em 29 de abril de 2013)

(Received on February 2, 2012; accepted on April 29, 2013)

$\mathrm{L}$ ettuce (Lactuca sativa) is the most cultivated vegetable in NFT hydroponic system (Nutrient Film Technique). This is due to its easy adaptation to the system, which has been showing high productivity and reduction in cycle in comparison to the soil cultivation (Ohse et al., 2001). In tropical environment, the lettuce crop cycle is about 70 days in conventional growth, whereas in hydroponics system it can be of 40 days (Cometti et al. 2008).

Hydroponics has been used especially in areas close to major urban centers, which has climatic characteristics of high temperature. This condition makes the vegetable cultivation a challenge, because if the root zone temperature is not controlled, the plant growth in mild climate reduces (He \& Lee, 1998).

The solution temperature affects the oxygen content and, in lettuce, when the temperature is high, it can cause the root death and accelerate the bolding process. In this case, it is recommended that the temperature does not exceed $20^{\circ} \mathrm{C}$
(Magalhães, 2006).

The cooling of nutrient solution has proved to be viable for the strawberry productivity (Mary, 2004; Villela Júnior et al., 2004). Studying the sweet pepper crop subjected to different temperatures of nutrient solution under hydroponic growing conditions, Dodd et al. (2000) concluded that the crop growth accelerates when exposed to a temperature of $20^{\circ} \mathrm{C}$, comparing to a temperature of $30^{\circ} \mathrm{C}$. Frantz et al. (2004) observed that temperatures between 27 and $30^{\circ} \mathrm{C}$ (aboveground part and nutrient 
solution) provided higher daily carbon gain, influenced positively the leaf expansion allowing plants to get close to the maximum of photosynthetic photon flux absorption on the $16^{\text {th }}$ day.

One of the characteristics of hydroponic cultivation is the ability to control the temperature of the nutrient solution or of the root system using heaters or cooling spiral, to increase or decrease the temperature, respectively. Relatively small changes in temperature of the root environment can cause significant impact on the root development, depending on phenological stage and duration of temperature (Rodrigues, 2002). Thus, the control of temperature of the nutrient solution could be a viable and more economic alternative in relation to the control of the entire protected environment.

Another very important characteristic of the nutrient solution is the electrical conductivity (EC). The changes in water absorption and nutrients, provided by the conductivity variation of the nutrient environment, lead to alterations in stomatal opening and leaf area growth, which are closely related to photosynthetic efficiency and, consequently, with the production of dry mass by the plants (Costa et al., 2001).

Some authors diverge about the best electrical conductivity value to be used for the hydroponic lettuce cultivation. According to Helbel Júnior et al. (2007), these values may vary depending on the cultivar and the climatic conditions. Soares (2002) states that an ideal EC of the nutrient solution is between 1.6 and $1.8 \mathrm{dS} \mathrm{m}^{-1}$ for the hydroponic lettuce crop in hot weather regions. However, according to Cometti et al. (2008), in regions with high temperature and high photosynthetic photon flux, the electrical conductivity of the nutrient solution for hydroponic lettuce, NFT, can be equal to $1.0 \mathrm{dS} \mathrm{m}^{-1}$, because the use of fertilizers is rationalized, reducing the production cost throughout the production, without compromising productivity.

According to Steidle Neto et al. (2005), EC depends on the temperature of the nutrient solution, in such a way that, if the temperature increases, the resistance of the solution decreases to the passage of electric current, resulting in increasing the conductivity.

This research aimed to evaluate the effect of cooling and electrical conductivity of the nutrient solution in yield of hydroponic lettuce.

\section{MATERIAL AND METHODS}

The experiment was carried out in November and December 2010, in protected environment, at Instituto Federal do Espírito Santo, in Colatina, Brazil (19³0'S, $40^{\circ} 20^{\prime} \mathrm{W}$, altitude of 70 $\mathrm{m})$, in the northwest region of Espírito Santo state. The area is characterized by dry tropical Aw.

During the experiment the average air temperature ranged from 21.1 to $30.6^{\circ} \mathrm{C}$ and the temperature of the nutrient solution of the border and the treatments, which did not have control of temperature, ranged from 24.0 to $29.9^{\circ} \mathrm{C}$ (Figure 1A). The photosynthetic photon flux (PPF) ranged from 60 to 1734 umol m-2 $\mathrm{s}^{-1}$ from 6 a.m. to 8 p.m. (Figure 1B).

The NFT hydroponic system was composed of four 3-meter-long benches, containing eight profiles of polypropylene with $75 \mathrm{~mm}$ diameter, spaced at $25 \mathrm{~cm}$, with 10 plants each, also spaced at $25 \mathrm{~cm}$.

The experiment was carried out in a factorial scheme $2 \times 3$, in completely randomized design with four replications composed of ten plants each. The factors were: control of the maximum temperature of the nutrient solution at $26^{\circ} \mathrm{C}$ (with and without) and the electrical conductivity (EC) and the nutrient solution $(1,2$ and $3 \mathrm{dS}$ $\left.\mathrm{m}^{-1}\right)$. The border corresponded to two side channels of each bench, whereas the treatments corresponded to the six internal channels. Each bench was considered one replication, containing one channel of each treatment, randomly positioned in each bench. The system was composed of seven independent hydroponic sub-systems (six for the treatments and one for the border). Each subsystem was constituted of one nutrient solution reservoir of $50 \mathrm{~L}$ and motor pump set of $1 / 3 \mathrm{CV}$.
To control the maximum temperature of the nutrient solution, a cooling system was used, however without controlling the minimum temperature.

The cooling system was composed of one horizontal freezer used as a chiller of a cooling solution, ethyl alcohol, diluted at $25 \%$ (freezing point of $-14.72^{\circ} \mathrm{C}$ ). A centrifugal pump was installed (washing machine) to press down the cooling liquid, which was distributed through PVC tubes, passing through a coil of a polyethylene flexible hose with a thin wall of $16 \mathrm{~mm}$ diameter, like the one used in localized irrigation. The return of the cooling liquid to the freezer was through PVC tubing of 16 $\mathrm{mm}$ diameter. The cooling liquid flux through the coil was automated by a temperature controller with Pt 100 sensor for each hydroponic subsystem, set at $26^{\circ} \mathrm{C}$ for closing the control valve of the cooling liquid flux (like solenoid of inlet water of a washing machine), controlled by a relay opening/closing circuit type.

The lettuce, cultivar Vitória de Santo Antão, was grown in phenolic foam, irrigated for five days with only water. Then, the cells were detached and transplanted to the nursery, being given standard nutrient solution from Setor de Horticultura do Instituto Federal de Educação Ciência e Tecnologia do Espírito Santo, Campus Itapina, adapted by Cometti et al. (2006) with $\mathrm{EC}=1.0$ $\mathrm{dS} \mathrm{m} \mathrm{m}^{-1}$. The seedlings were transplanted at 21 days after sowing (DAS) to the channels of final planting, being given treatment solutions.

The nutrient solution used was composed of $\left(\mathrm{mg} \mathrm{L}^{-1}\right)$ the following nutrients: $\mathrm{N}-\mathrm{NO}_{3}{ }^{-}=105.6 ; \mathrm{N}^{-} \mathrm{NH}_{4}^{+}=$ 12.3; $\mathrm{P}=29 ; \mathrm{K}=184 ; \mathrm{S}_{-} \mathrm{SO}_{4}{ }^{2-}=29$; $\mathrm{Ca}=56 ; \mathrm{Mg}=21 ; \mathrm{Fe}=1.8 ; \mathrm{Mn}=0.65$; $\mathrm{B}=0.26 ; \mathrm{Zn}=0.07 ; \mathrm{Cu}=0.04 ; \mathrm{Mo}=$ 0.03 , divided in solution $\mathrm{A}, \mathrm{B}$ and $\mathrm{M}$. Solution A for $1 \mathrm{~L}$ of concentrated solution: $170 \mathrm{~g}$ of potassic saltpeter, $37.5 \mathrm{~g}$ of monoammonium phosphate, $75 \mathrm{~g}$ of magnesium sulfate. Solution B for $1 \mathrm{~L}$ of concentrated solution: 110 $\mathrm{g}$ of calcium nitrate. Solution B for 1 L of concentrated solution: $100 \mathrm{~g}$ of ferrilene, $16 \mathrm{~g}$ of manganese sulfate, 2.5 of boric acid, $2 \mathrm{~g}$ of zinc sulfate, 1 $\mathrm{g}$ of copper sulfate and $0.4 \mathrm{~g}$ of sodium 
molybdate. From these concentrated solutions, the treatment solutions, with different conductivities, were prepared. For the nutrient solution with EC 1 $\mathrm{dS} \mathrm{m} \mathrm{m}^{-1}$ were added $2 \mathrm{~mL} \mathrm{~L}^{-1}$ of water from the solution $\mathrm{A}, 2 \mathrm{~mL} \mathrm{~L}^{-1}$ of water from the solution $B$ and $0.1 \mathrm{~mL} \mathrm{~L}^{-1}$ of water from the solution $\mathrm{M}$. In order to vary the electrical conductivity of the treatments, concentrated solutions were used proportionally, reaching 1, 2 and $3 \mathrm{dS} \mathrm{m}^{-1}$.

Nutrient solution corrections were performed daily, by adding water and stock solutions, following the electrical conductivity reading with a conductivity meter (Hanna, model HI 98130). The monitoring of environmental variables was performed by sensors (PPF - Licor radiometer sensor, air temperature and solution temperature - thermistor model 109 Campbell Scientific) connected to a datalogger (Campbell Scientific inc. RL 205, 900 MHz, Spread Spectrum Radio Logan, Utah, USA).

The harvest was performed at 52 DAS and evaluated: fresh mass of leaves, stem and root (LFM, SFM and RFM, respectively), dry mass of leaves, stem and root, obtained by drying in greenhouse at $80^{\circ} \mathrm{C}$ up to constant mass (LDM, SDM, RDM, respectively), root volume, stem and root length (RV, SL and RL, respectively), and plant water content ( $\%$ water). The analysis of variance of each evaluated characteristic was performed and comparison of average by Tukey test at 5\% probability, using the SigmaStat ${ }^{\circledR}$ program. To make the graphs, the program SigmaPlot ${ }^{\circledR}$ was used.

\section{RESULTS AND DISCUSSION}

For LFM, LDM, SDM, RDM, RV and RL an interaction of temperature control and electrical conductivity was noticed, and the levels of the electrical conductivity were evaluated in each temperature (Figure 2).

For LFM, LDM, SDM, RDM, $\mathrm{RV}$ and RL no significant difference between conductivities was noticed, when the temperature control $\left(26^{\circ} \mathrm{C}\right)$ was used. However, in the treatments without the temperature control, better performance for LFM, LDM, RDM, RV and RL was obtained in EC $1 \mathrm{dS} \mathrm{m}^{-1}$, which results did not differ from the ones obtained in EC 1, 2 and $3 \mathrm{dS} \mathrm{m}^{-1}$ with control of maximum temperature (Figure 2).

For LFM, when the temperature control $\left(26^{\circ} \mathrm{C}\right)$ was used, an increase of $11.9,44.1$ and $122.5 \%$ was observed in EC 1, 2 and $3 \mathrm{dS} \mathrm{m}^{-1}$, respectively, related to the treatments without temperature control of nutrient solution, using the same electrical conductivity. Therefore, the temperature control annulled the negative effect of the increase of EC on lettuce growth verified without the control of the maximum temperature. For SFM, RFM and SL, no significant interaction between the factors was observed (Figure 3).

Evaluating the temperature, the study pointed that SFM (Figure 3A) showed better performance when the temperature control was used. When the EC of nutrient solution was evaluated, the study showed that SFM (Figure $3 \mathrm{~B})$ at EC of $1 \mathrm{dS} \mathrm{m}^{-1}$ is greater than the one at $3 \mathrm{dS} \mathrm{m}^{-1}$, however it did not differ from the one at $2 \mathrm{dS} \mathrm{m}^{-1}$. For RFM (Figures 3C and 3D) and SL (Figures 3E and $3 \mathrm{~F}$ ) no significant differences were observed between the temperatures and the electrical conductivity tested.

Studying the percentage of water present in plants, no interaction between the electrical conductivity factors and the temperature control of nutrient solution was observed. Lettuce plants show higher percentage of water with EC of $1 \mathrm{dS} \mathrm{m}^{-1}$ than the ones with EC of $3 \mathrm{dS} \mathrm{m}^{-1}$, however both of them did not differ from the ones with EC of 2 $\mathrm{dS} \mathrm{m}^{-1}$ (Figure $3 \mathrm{H}$ ). According to the temperature of the nutrient solution, this study showed higher percentage of water in plants grown with the cooling of nutrient solution $\left(26^{\circ} \mathrm{C}\right)$ related to the plants grown without temperature control (Figure 3G). The average values increased from 94.6 to $95.2 \%$ with temperature control at $26^{\circ} \mathrm{C}$.

Evaluating the temperature, the study pointed that SFM (Figure 3A) showed better performance when the temperature control was used. When the EC of nutrient solution was evaluated, the study showed that SFM (Figure 3B) at EC of $1 \mathrm{dS} \mathrm{m}^{-1}$ is greater than the one at $3 \mathrm{dS} \mathrm{m}^{-1}$, however it did not differ from the one at $2 \mathrm{dS} \mathrm{m}^{-1}$. For RFM (Figures 3C and 3D) and SL (Figures 3E and $3 F$ ) no significant differences were observed between the temperatures and the electrical conductivity tested.

The performance of lettuce in relation to electrical conductivity of the nutrient solution changed according to the temperature. The temperature control of the solution allowed the increase of EC up to $3 \mathrm{dS} \mathrm{m}^{-1}$ without affecting the growth of lettuce. However, significant looses in some characteristics of the lettuce growth were observed, in solution without the temperature control, as EC was increased. The results observed can be explained by the

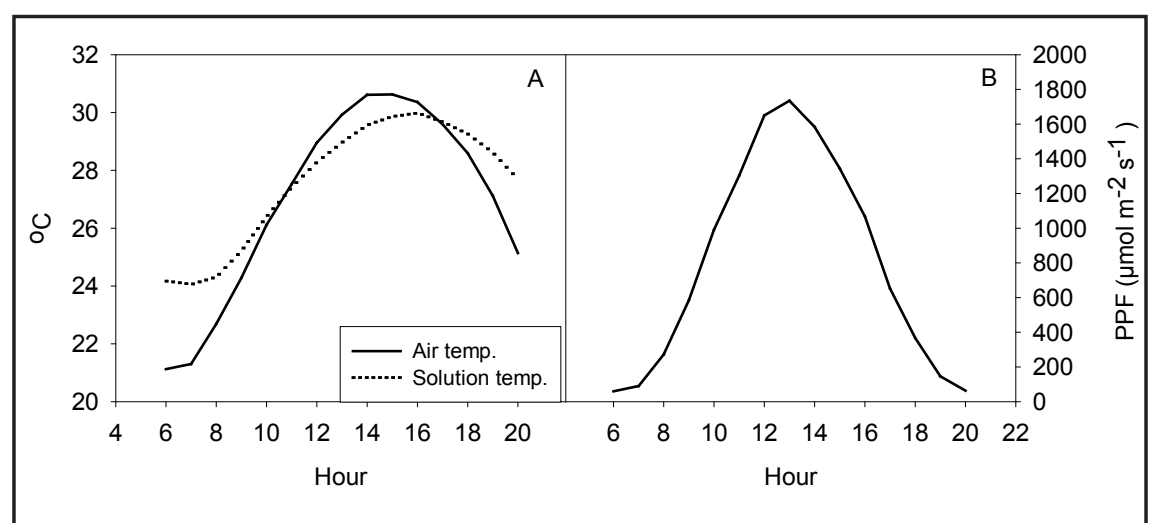

Figure 1. Temperature of the air and nutrient solution of border (A), and photosynthetic photon flux (PPF) (B) observed during the experiment [temperatura do ar e da solução da bordadura (A) e fluxo de fótons fotossintéticos (PPF) (B) observados durante o experimento]. Colatina, IFES, 2010. 


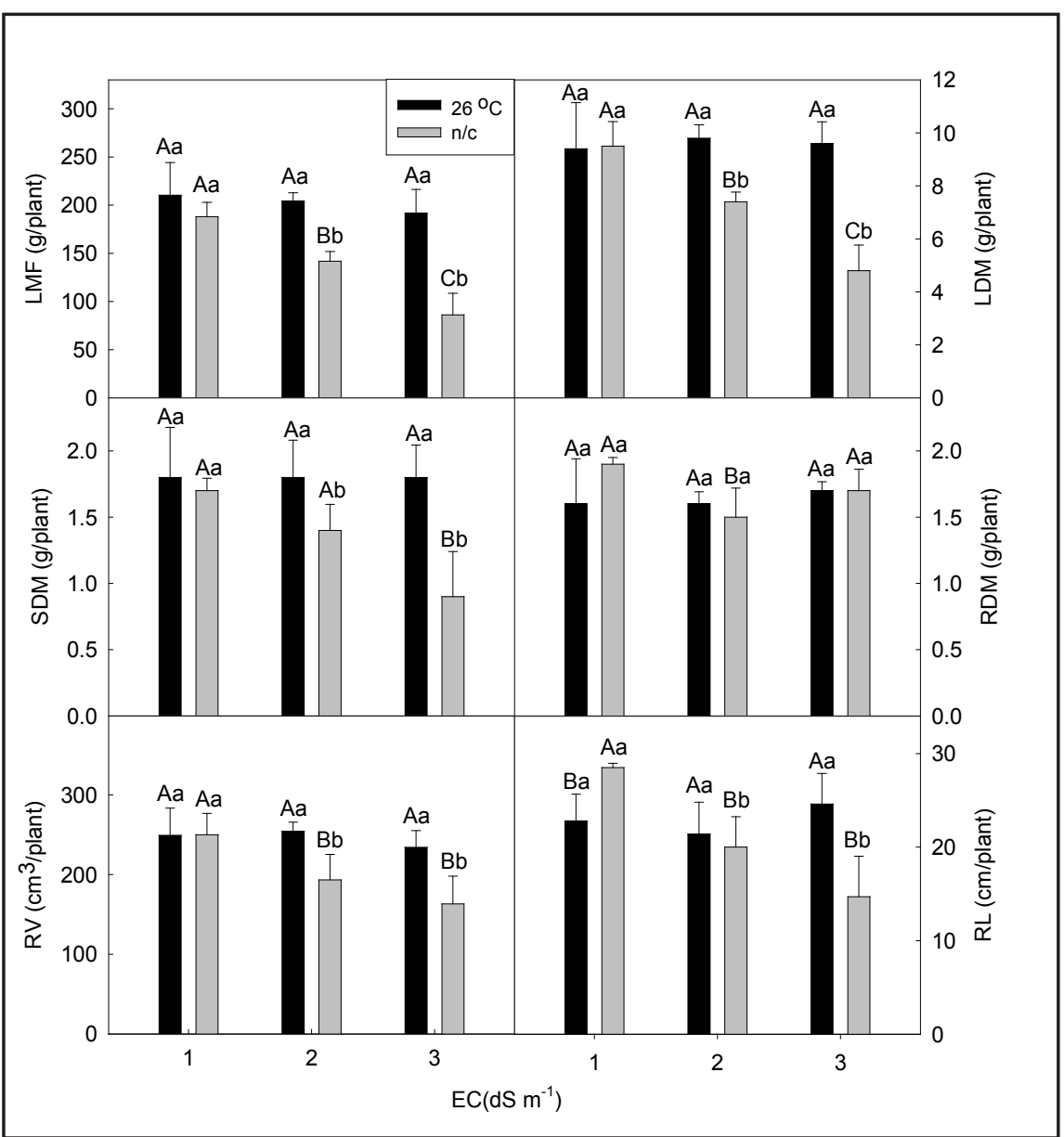

Figure 2. Leaves fresh mass (LFM), leaves dry mass (LDM), stem dry mass (SDM), root dry mass (RDM), root volume (RV) and root length (RL) of lettuce cv. Vitória de Santo Antão depending on the cooling and electrical conductivity of the nutrient solution, at 52 days after sowing. Capital letters compare temperature control and lower case letters, electrical conductivity, by Tukey test at $5 \%$ probability. "n/c" - no control [massa fresca de folhas (LFM), massa seca de folhas (LDM), massa seca de caule (SDM), massa seca de raiz (RDM), volume de raiz (RV) e comprimento de raiz (RL) da alface cv. Vitória de Santo Antão em função do resfriamento e da condutividade elétrica da solução nutritiva, aos 52 dias após a semeadura. Letras maiúsculas comparam controle de temperatura e letras minúsculas, condutividade elétrica, pelo teste de Tukey a $5 \%$ de probabilidade. "n/c" - sem controle]. Colatina, IFES, 2010.

reduction of oxygen in nutrient solution when the temperature increases, because in the solution with temperature control was measured $9.3 \mathrm{mg} \mathrm{L}^{-1}$ of $\mathrm{O}_{2}$, whereas in nutrient solution without temperature control, it was $6.2 \mathrm{mg} \mathrm{L}^{-1}$. According to Morgan (2002), in hydroponics growing systems, the quantity of oxygen $\left(\mathrm{O}_{2}\right)$ dissolved into solution is closely related to the temperature of the nutrient solution. With the increase of the temperature of the solution, the dissolved $\mathrm{O}_{2}$, which was "trapped", falls off, falling to limiting levels for cellular respiration and root growth.

The average values of water registered, at $52 \mathrm{DAS}$, were $95.3 \%$ when air evaporative demand, in a way that the stomata limit the gas exchanges and, consequently, the assimilation of $\mathrm{CO}_{2}$, besides maintaining reduced water availability for anabolic process (Barbieri et al., 2010).

The high electrical conductivity of the nutrient solution decreases the possibility of water absorption by the plant, decreasing the photosynthesis. The decrease in osmotic potential caused by the increase of salinity, and consequently in hydric potential cause inhibition of plant growth, photosynthesis, excessive accumulation of ions causing toxicity, inhibition of cell division and protein synthesis, resulting in a lower leaf area (Taiz \& Zeiger, 2004). At high temperatures, the nutrient solution should be further diluted to enable proper growth of the plants (Cometti et al. 2008). Thus, the temperature control of the solution minimizes the effect of $\mathrm{EC}$, to maintain the high level of $\mathrm{O}_{2}$, keeping the cellular respiration in the root in suitable level for the conservation of the control of water and nutrient absorption through the root cells. The photorespiration is favored by the increase of the leaf temperature, to a certain degree, because the solubility of $\mathrm{CO}_{2}$ in aqueous solution tends to decrease more rapidly than the $\mathrm{O}_{2}$ as the leaf temperature increases. The changes in the ratio $\mathrm{O}_{2}: \mathrm{CO}_{2}$ alter rates of $\mathrm{CO}_{2}$ fixation and photorespiration rates due to the competitive nature of these two substrates at the active site of RUBISCO (Majerowicz, 2008). As previously mentioned, the increase in EC with high-temperature reduced the water content in the plant, probably reducing photosynthesis, which can be observed in Figure 3G, where the percentage of water in the plants with a controlled temperature was higher than in plants where no control was used. This was also observed by Barbieri et al. (2010) who, testing EC $(0.5 ; 0.75 ; 1.0 ; 1.5 ; 2.0$; and $2.5 \mathrm{dS} \mathrm{m}^{-1}$ ), in hydroponic lettuce cultivation, in tropical environment, observed a variation from 95.5 to $94 \%$ of water in aboveground part tissue, increasing from $0.5 \mathrm{dS} \mathrm{m}^{-1}$ up to $1 \mathrm{dS} \mathrm{m}^{-1}$ and falling to $2 \mathrm{dS} \mathrm{m}^{-1}$, when stabilized.

The cooling of the nutrient solution provided higher fresh mass of leaves 


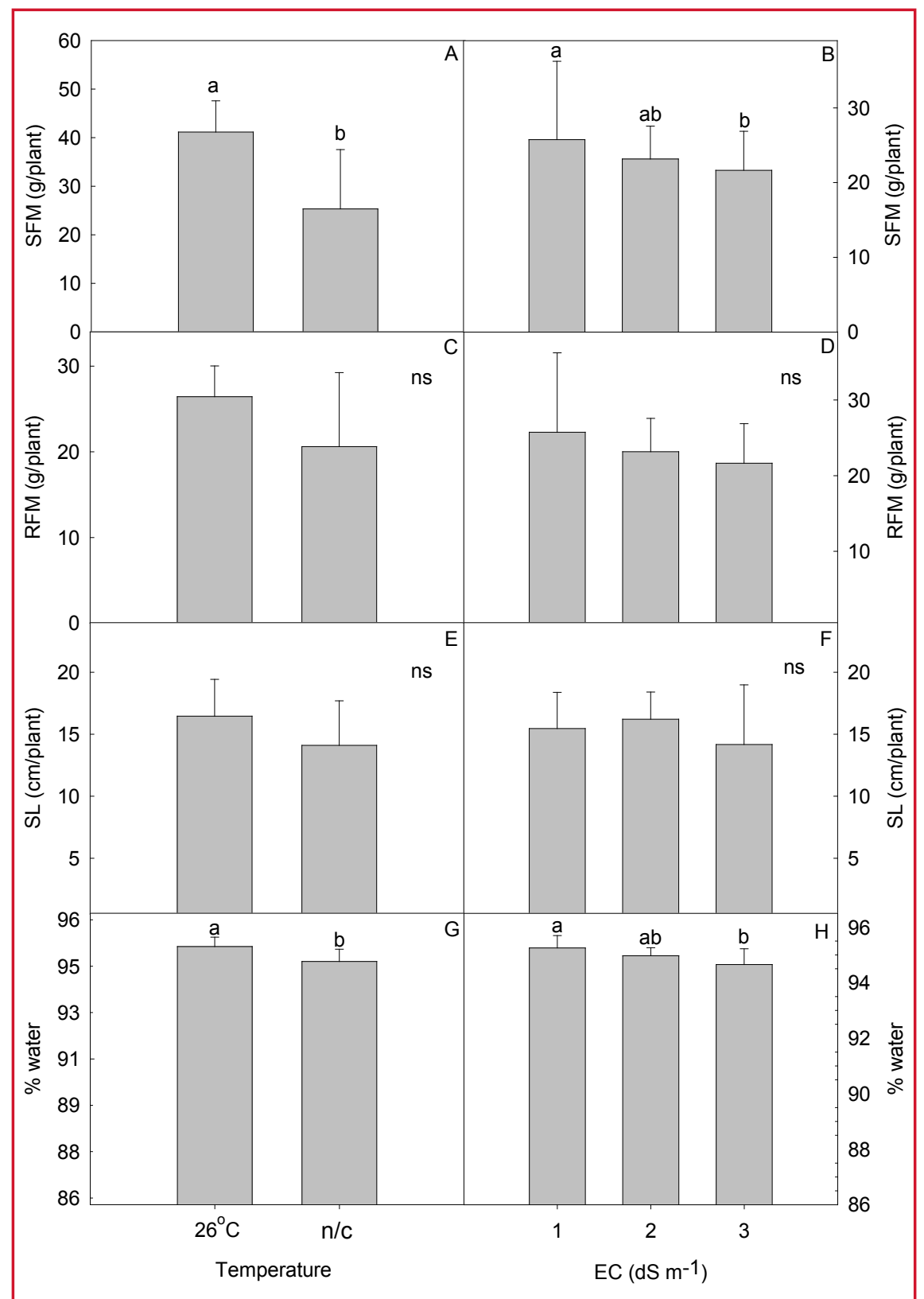

Figure 3. Stem fresh mass (SFM), root fresh mass (RFM), stem length (SL) and percentage of water present in plants (\% water) of lettuce cv. Vitória de Santo Antão depending on the electrical conductivity and cooling of nutrient solution, at 52 days after sowing. Lowecase letters compare means by Tukey test at $5 \%$ probability. "ns" not significant at $5 \%$ probability by the F test. "n/c" - no control [massa fresca de caule (SFM), massa fresca de raiz (RFM), comprimento de caule (SL) e porcentagem de água presente nas plantas (\% water) da alface cv. Vitória de Santo Antão em função da condutividade elétrica e do resfriamento na solução nutritiva, aos 52 dias após a semeadura. Letras minúsculas comparam médias pelo teste de Tukey a 5\% de probabilidade. "ns" não significativo ao nível de $5 \%$ de probabilidade pelo teste F. "n/c"- sem controle]. Colatina, IFES, 2010.

and stem, higher volume of roots, dry mass of leaves and roots and higher percentage of water in the plants. According to Rodrigues (2002), the temperature changes can affect the permeability of the cells, the speed of transfer processes and the occurrence increase of EC from 1 to $3 \mathrm{dS} \mathrm{m} \mathrm{m}^{-1}$ cause reduction in growth of lettuce cv. Vitória de Santo Antão grown in hydroponic NFT, when no temperature control, maximum $26^{\circ} \mathrm{C}$, is used. The cooling of the solution provides higher mass accumulation of shoot and higher percentage of water in plants, increasing lettuce growth in hydroponic in tropical weather conditions.

\section{ACKNOWLEDGEMENTS}

To Mr. Marinaldo Francisco Zanotelli and Éder Wilson Lerbach Pereira, both of Setor de Horticultura do IFES, Campus Itapina for the aid and support to carry out this work. To FAPES for the Master scholarship for the second and third authors of this study. To IFES for the Scientific Initiation scholarship for the fourth author. To Hidrogood Horticultura Moderna for granting of hydroponic profiles. To the Scientific Initiation students Gabriel Passos, Eline Paula Figueira Cazaroti, Mathias Stinghel and Fernando Maximiliano Pereira for collaboration in this work.

\section{REFERENCES}

BARBIERI E; MELO DJF; ANDRADE LF; PEREIRA EWL; COMETTI NN. 2010. Condutividade elétrica ideal para o cultivo hidropônico de alface em ambiente tropical. Horticultura Brasileira 28: S303-S308.

COMETTI NN; MATIAS GCS; ZONTA E; MARY W; FERNANDES MS. 2008. Efeito da concentração da solução nutritiva no crescimento da alface em cultivo hidropônico - sistema NFT. Horticultura Brasileira 26: 252-257.

COMETTI NN; FURLANI PR; RUIZ HA; FERNANDES FILHO EI. 2006. Soluções nutritivas: formulação e aplicações. In: MANLIO SF. (ed). Nutrição mineral de plantas. Viçosa: Sociedade Brasileira de Ciência do Solo. p. 89-114.

COSTA PC; DIDONE EB; SESSO TM; CAÑIZARES KAL. 2001. Condutividade elétrica da solução nutritiva e produção de alface em hidroponia. Scientia Agricola 58: 595-597.

DODD IC; HE J; TURNBULL CGN; LEE SK; CRITCHLEY, C. 2000. The influence of supraoptimal root-zone temperatures on growth and stomatal conductance in Capsicum annum $\mathrm{L}$. Journal of Experimental Botany 51: 239-248.

FRANTZ JM; RITCHIE G; COMETTI NN; ROBINSON J; BUGBEE B. 2004. Exploring the limits of crop productivity: beyond the limits of tipburn in lettuce. Journal of the 
American Society for Horticultural Science 129: 331-338.

HE J; LEE SK. 1998. Growth and photosynthetic characteristics of lettuce (Lactuca sativa L.) under fluctuation hot ambient temperatures with the manipulation of cool root-zone temperature. Journal of Plant Physiology 152: 387-391.

HELBEL JUNIOR C; REZENDE R; SANTOS HS; FREITAS PSL; AZEVEDO TLF; FRIZZONE JA. 2007. Soluções nutritivas, vazões e qualidade da alface hidropônica. Acta Scientiarum Agronomy 29: 291-295.

MAGALHÃES AG. 2006. Caracterização de genótipos de alface (Lactuca sativa L.) em cultivo hidropônico sob diferentes valores de condutividade elétrica da solução nutritiva. Recife: UFRPE. 95p (Dissertação mestrado). MAJEROWICZ N. 2008. FoStossíntese. In:
KERBAUY GB. Fisiologia Vegetal $-2^{\mathrm{a}}$. ed. Rio de Janeiro: Guanabara Koogan. p. 82-133.

MARY W. 2004. Desenvolvimento e análise de parâmetros ambientais em estrutura de proteção construida com bambu e de sistemas hidropônicos com zona de resfriamento. Campinas: Unicamp. 163p (Tese doutorado).

MORGAN L. 2002. Nutrient temperature, oxygen and pithier in hydroponics. Disponível em: $<$ http://www.quickgrow.com>. Acesso em 21 de setembro de 2011.

OHSE S; DOURADO-NETO D; MANFRON PA; SANTOS OS. 2001. Qualidade de cultivares de alface produzidos em hidroponia. Scientia Agricola 58: 181-185.

RODRIGUES LRF. 2002. Cultivo pela técnica de hidroponia: técnicas de cultivo hidropônico e de controle ambiental no manejo de pragas, doenças e nutrição vegetal em ambiente protegido. Jaboticabal: FUNEP, 726p.

SILVA JO; SOUZA PA; GOMES JÚNIOR J; PEREIRA PRG; ROCHA FA. 2005. Crescimento e composição mineral da alface no sistema hidropônico por capilaridade. Irriga 10: $146-154$.

SOARES I. 2002. Alface: cultivo hidropônico. Fortaleza: UFC, 50p.

STEIDLE NETO AJ; ZOLNIER S; MAROUELLI WA; CARRIJO OA; MARTINEZ HEP. 2005. Avaliação de um circuito eletrônico para medição da condutividade elétrica de soluções nutritivas. Engenharia Agrícola 25: 427-435.

TAIZ L; ZEIGER E. 2004. Fisiologia vegetal. 3.ed. Porto Alegre: Artmed, 720p.

VILLELA JUNIOR LVE; ARAUJO JAC; FACTOR TL. 2004. Análise do resfriamento da solução nutritiva para cultivo hidropônico do morangueiro. Engenharia Agrícola 24: 338-346. 